\title{
ANALISIS PENDAPATAN USAHA PERIKANAN TANGKAP : PENGALAMAN DARI NELAYAN KABUPATEN GARUT JAWA BARAT
}

\author{
Intan Tenisia Prawita Sari ${ }^{1}$ \\ Universitas Garut \\ intantenisia@uniga.ac.id \\ Mohamad Iqbal Abdul Rauf ${ }^{2}$ \\ Universitas Garut \\ mi.abdulrauf@gmail.com
}

\begin{abstract}
Abstrak - Indonesia sebagai Negara kepulauan mempunyai sumber daya di sektor perikanan dan kelautan yang sangat tinggi dimana sumber daya ini menjadi senjata dalam peningkatan kesejahteraan rakyat khususnya dan menjadi modal dalam pola pembangunan nasional. Namun, kemiskinan masih menjadi ikon bagi nelayan. Pendapatan nelayan tangkap dapat dikatakan berbeda dengan jenis usaha lainnya karena usaha penangkapan ikan tidak menentu yang dimana pendapatannya tersebut berfluktuasi dan berspekulasi sehingga dapat memacu terhadap tumbuhnya kemiskinan. Tujuan yang ingin dicapai dalam penelitian ini adalah untuk mengungkap dan menganalisis hal-hal yang berpengaruh terhadap pendapatan nelayan perikanan tangkap. Adapun, metode deskriptif eksplanatori penulis ambil sebagai Metode penelitian. Pengambilan data berasal dari 100 responden nelayan dengan bahasan profil nelayan berupa umur, pendidikan, tanggungan keluarga, pengalaman dan lama melaut. Selanjutnya, dalam menganalisis data digunakan metode regresi kuadrat terkecil (OLS). Berdasarkan penelitian yang dilakukan semua responden adalah pria sejumlah 100 orang (100\%). Hasil pendapatan mengindikasikan bahwa semakin sulitnya nelayan mendapat ikan di perairan Kabupaten Garut padahal MSY lestari di kabupaten Garut adalah 10.000 ton/tahun dan hal ini cukup besar untuk para nelayan tangkap dengan hasil yang lebih besar. Selanjutnya ditemukan pula bahwa variabel umur, tanggungan keluarga, pendidikan pengalaman dan lama melaut berpengaruh secara simultan signifikan terhadap pendapatan usaha nelayan. Sementara itu, apabila secara parsial ditemukan cuma 4 variabel yang berpengaruh secara positif terhadap pendapatan usaha tangkap yaitu lama melaut, umur nelayan, tanggungan keluarga dan pengalaman. Sedangkan pendidikan formal tidak berpengaruh secara nyata terhadap pendapatan usaha nelayan. Pemerintah Kabupaten Garut diharapkan dapat membantu nelayan dalam kelembagaan nelayan dengan keanggotaan yang bervariasi antara usia, pengalaman melaut dan tanggungan keluarga, selanjutnya Pemerintah daerah dalam memberikan bantuan sarana dan prasarana penangkapan dan akses ke permodalan melalui rekomendasi ke bank guna meningkatkan armada tangkap nelayan yang ujungnya berguna dalam peningkatan kesejahteraan nelayan.
\end{abstract}

Kata Kunci: pendapatan, nelayan, perikanan tangkap, fungsi produksi, Garut 
Abstract - Indonesia's potention on marine and fisheries resources is very large. This can be used to increase people's welfare and enhance capital in the pattern of Indonesia income. However, poverty is still an icon for fishermen. Captured fishermen's income can be said to be different from other types of businesses because fishing businesses are full of uncertainties and are speculative and fluctuate so that they can spur the growth of poverty. The aim of the study is to analyze the factors which influence the income of capture fishermen. The method that use is an explanatory descriptive method. All data is taken from 100 fishermen respondents that is the profile of fishermen in the form of age, education, family dependence, experience and length of time at sea. The data analysis method used is the least squares method regression (OLS). From the results of the study, it was found that the sex of the whole respondent was male, which amounted to 100 people (100\%). The income results indicate that it is increasingly difficult for fishermen to get fish in the waters of Garut Regency even though the sustainable MSY in Garut regency is 10,000 tons / year and this is quite large for capture fishermen to have highly amount of fishes. Furthermore, the finding also embodied that simultaneously the variables of age, education, family dependence, experience and length of time had a significant effect on the income of fishermen's businesses. For the meantime, partially there are 4 variables that positively influence capture business income, namely length of fishing, age of fishermen, family dependence and experience. While formal education does not significantly disturb the income of fishermen's businesses. Government of Garut Regency is expected to assist fishermen in the making of organization of fishermen with a variety of participants including, age, experience at sea and family dependents, then the local government should providing fishing facilities and infrastructure assistance in order to increase the fishing fleet whose in the ends are beneficial in the Improvement fisherman welfareness.

Keywords: income, fishermen, capture fisheries, production function, Garut

\section{PENDAHULUAN}

Indonesia berbentuk kepulauan dan merupakan salah negara dengan luas wilayah pesisir terbesar didunia dimana panjang pantai sejauh $99.093 \mathrm{~km}^{2}$ dan luas perairan sebesar $6.315 .222 \mathrm{~km}^{2}$. Sehingga, sudah semestinya potensi sumber daya disektor perikanan dan kelautan yang tinggi bisa berguna dalam peningkatan kesejahteraan rakyat khususnya dan menjadi modal dalam pola pembangunan nasional. Pelaku utama dalam mengekstraksi sumber daya kelautan dan perikanan ini adalah nelayan. Namun, hal yang kontradiksi terjadi dimana nelayan merupakan ikon kemiskinan di Negara-negara berkembang (Salagrama, 2006). Hal ini dipengaruhi oleh secara luas oleh socioinstitusional factor (Béné \& Friend, 2011). Begitu pula yang terjadi di Indonesia. Kemiskinan ini menjadi masalah dalam pembangunan di Indonesia dan bersifat multidimensional karena melibatkan bukan hanya hubungan sebab akibatnya tetapi juga menyangkut prefensi, nilai dan politik (Ali, Dharmawan, Saharuddin, Alfiasari, Sukandar, \& Syarief, 2015).

Penyebab kemiskinan di wilayah pesisir ini dianggap dipengaruhi oleh beberapa hal yang terbilang kompleks seperti pola pekerjaan dimana nelayan tidak bisa melakukan pekerjaan lain, tidak pastinya musim penangkapan ikan, terbatasnya akses modal dan sumber daya manusia dan akses perdagangan ikan dimana nelayan memiliki nilai tukar 
yang sangat rendah terhadap perbankan, serta tingkat pendapatan terus anjlok sementara kebutuhan pemenuhan rumah tangga semakin tinggi (Indarti \& Kuntari, 2015). Lebih lanjut (Kusnadi, 2009) berpendapat Pendapatan dari para nelayan perikanan tangkap khususnya tradisional tidak sama dengan jenis usaha yang lain, seperti petani dan pedagang dimana kegiatan usahanya bersifat tidak tetap dan tidak adanya kepastian dalam berusaha karena prosesnya fluktuatif dan spekulatif sehingga memacu terhadap tumbuhnya kemiskinan.

Adapun, penyebab utama nelayan menjadi miskin dapat ditinjau dari segi pendapatannya (Rahim, 2012). Produksi hasil penangkapan ikan menjadi tolak ukur dalam menentukan tingkat kesejahteraan nelayan. Sehingga, meningkatkan produksi tangkapan nelayan dapat menjadi faktor yang menentukan dan dapat menjadi solusi dalam meningkatkan kontribusi pendapatan nelayan dan menekan laju kemiskinan.

Demikian pula, terjadi fenomena yang sama terjadi di wilayah Kabupaten Garut. Garut adalah kota di wilayah selatan Jawa Barat yang memiliki pesisir. Dipercaya bahwa nelayan Kabupaten Garut termasuk golongan masyarakat miskin karena hasil pendapatan mereka tergolong rendah. Hal ini ditunjukkan oleh hasil tangkapan ikan yang sedikit dan tidak menentu jumlahnya. Terlebih dengan nilai penjualan hasil ikannya yang rendah. Padahal, diperkirakan potensi sumber daya kelautan di Kabupaten Garut masih sangat tinggi karena laut yang masih sangat bersih dan menghadap langsung ke Samudera Hindia di bagian selatan.

Berdasarkan hal itu maka perlu diketahui terlebih dahulu faktor-faktor yang memiliki kontribusi terhadap pendapatan usaha nelayan di pesisir Kabupaten Garut dan selanjutnya dalam jangka waktu panjang bisa dilakukan upaya peningkatan pendapatan dan kesejahteraan nelayan. Dengan demikian, Penelitian ini memiliki tujuan untuk mengungkap dan menganalisis hal-hal yang berdampak terhadap pendapatan para nelayan tangkap. Adapun manfaat yang bisa didapat dalam penelitian adalah sebagai bahan referensi bagi pihak yang berkepentingan dalam upaya dan strategi meningkatkan pendapatan guna kesejahteraan nelayan dimasa yang akan datang.

\section{KAJIAN LITERATUR}

\section{Nelayan}

Menurut (Monintja \& Yusfiandani, 2011) mempertimbangkan waktu yang diperlukan dalam pelaksanaan pekerjaan penangkapan maka nelayan diklasifikasikan menjadi:

a) Nelayan tetap atau nelayan penuh, yakni nelayan yang seluruh pendapatannya berasal dari menangkap ikan.

b) Nelayan sambilan utama, yakni nelayan yang sebagian besar pendapatannya berasal dari perikanan.

c) Nelayan sambilan tambahan, yakni nelayan yang pendapatannya hanya sebagian kecil berasal dari proses menangkap.

d) Nelayan musiman, yakni orang yang hanya aktif menangkap ikan pada musim tertentu saja.

\section{Pendapatan Nelayan dan Faktor yang mempengaruhinya}

Definisi pendapatan adalah jumlah total uang yang diterima oleh individu atau rumah tangga yang dilakukan pada waktu tertentu. Adapun, Pendapatan merupakan penerimaan upah para tenaga kerja, pendapatan lain-lain yang berasal dari kekayaan seperti bunga dan dividen, sewa, dan pembayaran transfer 
atau penerimaan dari pemerintah seperti tunjangan sosial atau asuransi pengangguran (Samuelson \& Nordhaus, 2010). Sementara dalam konteks usaha nelayan, pendapatan tidak dapat diprediksi semudah bidang usaha lain, karena kegiatan usaha nelayan ini tidak ada kepastian (uncertainty) dan cenderung spekulatif juga hasilnya fluktuatif (Wahyono, Antariksa, Imron, \& Indrawasih, 2001).

Pendapatan di bidang usaha nelayan ini dapat dipengaruhi oleh beberapa faktor. secara umum beberapa komponen yang berpengaruh terhadap penghasilan nelayan dari usaha menangkap ikan adalah lokasi penangkapan, biaya bahan bakar dan modal untuk pergi ke laut serta faktor nonfisik yang berkaitan dengan iklim dan musim, usia nelayan, pendidikan terakhir nelayan, dan lama pengalaman melaut nelayan (Ismail, 2004). Lebih lanjut Ismail memaparkan pendapatnya bahwa setidaknya ada 6 variabel yang berpengaruh terhadap pendapatan nelayan yaitu modal melaut, kondisi lingkungan, pendidikan terakhir nelayan, teknologi penangkapan, umur dan pengalaman melaut.

\section{Teori dan Fungsi Produksi}

Definisi produksi adalah suatu aktivitas yang berupaya mengonversi sebuah masukan menjadi suatu luaran yang diinginkan (Sugiarto, Herlambang, Kelana, Brastoro, \& Sudjana, 2007). Sehingga, secara umum teori produksi dapat menggambarkan suatu hubungan level produksi dengan banyaknya tenaga kerja dalam menghasilkan tingkat produksi barang tersebut (Sudarman, 2011). Sehingga, Sasaran dalam teori produksi adalah penentuan efisiensi tingkat produksi dalam menggunakan sumber daya yang tersedia. Oleh karena itu, Pendapatan netto atau keuntungan dalam melakukan usaha pertanian mempergunakan rumus sebagai berikut (Rahim \& Hastusti, 2005) :

Atau

$$
\pi=T R-T C
$$

dimana :

$\pi$ : keuntungan

TC : total cost

TR : total revenue

TFC : total factor cost

TVP : total value of product

Sementara itu, fungsi produksi adalah sebuah aktivitas dalam upaya mengubah dan menambah fungsi sebuah barang dengan menggunakan sumber daya yang ada dan menghasilkan kepuasan bagi konsumen (Everett \& Ebert, 1992). Sehingga fungsi produksi merupakan rumus yang menggambarkan sifat hubungan antara faktor produksi dengan level produksinya. Adapun Persamaan fungsi produksi:

$$
\begin{aligned}
& \quad Q=f(L, C, R, S) \\
& \text { Dimana: } \\
& Q=\text { tingkat produksi yang dihasilkan } \\
& \mathrm{C}=\text { jumlah modal } \\
& \mathrm{L}=\text { tenaga kerja } \\
& \mathrm{S}=\text { kewirausahaan } \\
& \mathrm{R}=\text { kekayaan alam }
\end{aligned}
$$

Atau

$$
Q=f\left(X_{1}, X_{2}, X_{3}, \ldots, X_{n}\right)
$$

Dimana :

$\mathrm{Q}=$ Jumlah output yang dihasilkan

$\mathrm{x}_{1}, \quad \mathrm{x}_{2}, \mathrm{x}_{3} \quad \ldots, \mathrm{x}_{\mathrm{n}}=$ Faktor-faktor produksi (input) yang digunakan.

Dalam penelitian ini fungsi produksi yang dipakai yaitu fungsi produksi CobbDouglas. Adapun, rumusan fungsi produksi Cobb-Douglas merupakan sebuah persamaan yang yang terdiri atas dua atau lebih variabel. Adapun, variabel yang satu merupakan variabel dependen 


\section{ANALISIS PENDAPATAN USAHA PERIKANAN TANGKAP : PENGALAMAN DARI NELAYAN KABUPATEN GARUT JAWA BARAT}

atau variabel yang dijelaskan sedangkan variabel yang satu lagi merupakan variabel independen atau variabel yang menjelaskan (x) (Soekartawi, 2002). Lebih lanjut soekartawi memaparkan keunggulan penggunaan fungsi Cobb-Douglas yaitu :

1. Mudah merubah fungsi ke bentuk linear hanya dengan di logaritmakan

2. Besaran elastisitas fungsi dapat dilihat dari pendugaan koefisien regresi yang dihasilkan.

3. Selain itu besarnya elastisitas dapat menunjukkan level skala usaha apakah menaik, tetap ataukah turun.

4. Konsep Koefisien intersep dari fungsi adalah indeks langsung dari efisiensi produksi

5. Koefisien fungsi dapat dengan langsung menjelaskan elastisitas produksi

\section{Penelitian Terdahulu}

Halim \& Susilo (2013) melakukan studi yang bertujuan untuk mengetahui dampak variabel modal usaha, lama waktu di laut per perjalanan dan lama usaha terhadap pendapatan usaha perikanan di Kabupaten Bantul. Metode penelitian yaitu metode convienince sampling. Variabel independen dalam penelitian ini mampu menjelaskan $91,56 \%$ dari variabel yang dijelaskan (dependen). Kemudian, dari hasil statistik uji-t menggambarkan bahwa variabel modal usaha, lama waktu di laut per perjalanan dan lama usaha memiliki efek yang berdampak secara signifikan terhadap tingkat pendapatan komunitas nelayan pesisir di Bantul.

Putri \& Setiawina (2013) melakukan penelitian di Karangasem, Bali mengenai pengaruh pendidikan, usia dan jenis pekerjaan dibandingkan dengan pendapatan rumah tangga miskin. Dengan menggunakan jumlah populasi sejumlah 95 orang responden dan menggunakan teknik analisis data regresi linier berganda ditemukan bahwa secara simultan maupun parsial faktor pendidikan, usia, dan jenis pekerjaan, ternyata memiliki dampak yang signifikan kepada pendapatan rumah tangga miskin di yang berada di lokasi penelitian yaitu desa Bebandem, Karangasem. Secara mandiri, variabel umur, pendidikan dan jenis pekerjaan ternyata berpengaruh positif dan signifikan terhadap pendapatan, disisi lain variabel umur berpengaruh negatif terhadap pendapatan rumah tangga miskin di desa tersebut.

Puluhulawa, Rauf, \& Halid (2016) melakukan penelitian di Kecamatan Bilato Kabupaten Gorontalo. Metode analisis deskriptif dipilih sebagai metode dalam penggambaran trend jumlah tangkapan ikan kemudian analisis regresi linier berganda dipilih untuk melihat komponen yang berdampak terhadap hasil tangkapan nelayan. Selain itu, analisis pendapatan di pilih untuk menggambarkan besarnya pendapatan nelayan tangkap. Selanjutnya, diketahui bahwa variabel produksi perahu, modal, dan tenaga kerja dengan simultan berpengaruh positif kepada hasil tangkapan nelayan. Sementara itu, secara parsial ditemukan bahwa hanya faktor produksi modal ternyata berpengaruh secara nyata. Selain itu, tidak berpengaruh.

\section{Hipotesis}

Meninjau latar belakang yang diajukan dan pembahasan dalam tinjauan pustaka, dirumuskan hipotesis yaitu :

"Diduga bahwa umur, pendidikan, tanggungan keluarga, pengalaman, dan lama melaut berpengaruh signifikan terhadap pendapatan nelayan tangkap" 


\section{METODOLOGI PENELITIAN}

Metode deskripsi eksplanatori yang penulis gunakan dalam menjawab pertanyaan penelitian. Metode ini merupakan suatu metode yang berguna dalam menggambarkan objek yang diteliti melalui data baik itu sampel ataupun populasi dan kemudian langkah selanjutnya dilakukan analisis dan ditarik kesimpulan yang berlaku secara umum.

Sementara itu, teknik survei digunakan untuk memperoleh informasi dan data, Selanjutnya pengumpulan informasi tersebut menggunakan teknik survei berupa penyebaran melalui data kuesioner dan dokumentasi dianggap bisa menggambarkan faktor-faktor yang mempengaruhi pendapatan nelayan tangkap.

\section{Operasional Variabel}

variabel adalah objek yang akan dipelajari, dengan kata lain fenomena yang mempunyai bentuk variasi-variasi tersendiri yang akan diteliti dan diambil kesimpulan (Sugiyono, 2013). Jenis variabel yang digunakan adalah sebagai berikut :

1. Variabel Independen (X) adalah variabel yang berpengaruh atau faktor yang menjadi penyebab terjadinya perubahan variabel yang lain (Y) dimana dalam hal ini adalah variabel tersebut adalah variabel Umur $\left(\mathrm{X}_{1}\right)$, variabel Pendidikan $\left(\mathrm{X}_{2}\right)$, Variabel Tanggungan Keluarga $\left(X_{3}\right)$, Variabel Pengalaman $\left(\mathrm{X}_{4}\right)$, dan Variabel Lama Melaut ( $\left.\mathrm{X}_{5}\right)$.

2. Variabel dependen $(Y)$ merupakan variabel output atau variabel yang dipengaruhi oleh variabel independen yaitu pendapatan nelayan tangkap (mPNT) di Kabupaten Garut

\section{Sumber dan Cara Penentuan Data}

Penelitian ini menggunakan data baik berupa data primer maupun data sekunder. Data primer adalah data yang langsung diambil dari responden melalui penyebaran kuesioner.

Adapun, sumber data adalah para nelayan yang diambil data kepemilikan perahu/kapal perorangan kecil, informan (masyarakat di Tempat Pelelangan Ikan/TPI) di Kabupaten Garut sebagai populasi. Dimana jumlah sampelnya diambil sebanyak 100 Orang dengan metode random stratified sampling.

Data yang ditanyakan kepada responden adalah profil nelayan berupa umur, pendidikan, tanggungan keluarga, pengalaman dan lama melaut. Adapun, data sekunder merupakan data dari Dinas Perikanan dan Peternakan Kabupaten Garut.

\section{Perhitungan Frekuensi Skor}

Perhitungan frekuensi skor dilakukan untuk dalam rangka mencari secara umum deskripsi variabel penelitian. Dalam hal ini, frekuensi skor jawaban responden dihitung dan diperoleh persentase jawaban setiap alternatif jawaban. Five option scale digunakan sebagai penilaian jawaban kuesioner sehingga didapatkan data dalam skala ordinal. Selanjutnya, dalam penggunaan analisis data secara kuantitatif, maka data yang awalnya berbentuk skala ordinal harus ditransformasi menjadi skala interval melalui methods of successive interval (MSI).

\section{Metode Analisis Data}

Metode analisis data yang dipergunakan oleh penelitian adalah regresi metode kuadrat terkecil (OLS). Metode dianggap cukup memadai dalam analisis untuk mengestimasi variabel yang berpengaruh terhadap jumlah pendapatan nelayan tangkap di Kabupaten Garut dan tetap menimbang indikator Determinant Coefficient (R2), uji-F, dan uji-t. Uji ekonometri yang harus 
memenuhi ketentuan-ketentuan asumsi klasik sehingga dapat dipergunakan dalam proses mendeskripsikan suatu kejadian ekonomi secara lebih tepat (Gujarati \& Porter, 2009)

Lebih lanjut,

dalam

mengakomodasi kepentingan tersebut, penelitian ini menggunakan juga uji asumsi klasik berupa uji autokorelasi, uji heteroskedastisitas, dan

multikolenearitas.

\section{HASIL DAN PEMBAHASAN}

\section{Deskripsi Wilayah Penelitian}

Secara geografis Kabupaten Garut berada di Provinsi Jawa Barat bagian Selatan garis lintang Kabupaten Garut terletak pada posisi 6057'34" LS 7044'57" LS dan 107024'3" BT 108024'34" BT dengan luas areal $3.066,88 \mathrm{~km} 2$, kemudian mempunyai 42 kecamatan yang terdiri dari 403 desa dan 21 kelurahan. Dimana daerah tersebut mempunyai ciri-ciri khusus dan potensi wilayah yang berbeda baik segi sumber daya alamnya ataupun sumber daya manusianya. Selanjutnya, Wilayah Kabupaten Garut berada pada posisi dengan ketinggian tertinggi $1.244 \mathrm{~m} \mathrm{dpl}$ dan terendah $7 \mathrm{~m} \mathrm{dpl}$ dengan kontur wilayah berupa pegunungan, dataran rendah dan pantai. Adapun, batas-batas wilayah administratif sebagai berikut :

- Bagian Barat berbatasan dengan Kabupaten Bandung dan Kabupaten Cianjur

- Bagian Timur berbatasan dengan Kabupaten Tasikmalaya

- Bagian Utara berbatasan dengan Kabupaten Bandung dan Kabupaten Sumedang.

- Bagian Selatan berbatasan dengan Samudera Hindia.

Topografi di Kabupaten Garut sangat beragam. Dimana, pada umumnya kondisi Wilayah di bagian
Timur, Utara, dan Barat termasuk daerah dengan dataran tinggi berupa berbukitbukit dan pegunungan, sedangkan di daerah sebelah Selatan kontur permukaan tanahnya cenderung memiliki kemiringan yang relatif cukup curam. Selain itu, dipengaruhi oleh iklim Samudera Indonesia. Panjang garis pantai pesisir selatan Garut sepanjang $80 \mathrm{~km}$ yang meliputi Kecamatan Bungbulang, Caringin, Pakenjeng, Mekarmukti, Cikelet, Cibalong dan Pameungpeuk.

Potensi sumber daya ikan di pantai Garut dengan Zona Ekonomi Eksklusif (ZEE) yang memiliki areal penangkapan $28.560 \mathrm{~km}^{2}$ diestimasi dengan potensi lestarinya (MSY) sebanyak 10.000 ton. Sekitar 100 ribu jiwa (5\%) penduduk Kabupaten Garut bermata pencaharian sebagai pembudidaya ikan, nelayan, pengolah dan pemasaran hasil perikanan yang pada umumnya masih tergolong ke dalam skala ekonomi keluarga dengan menggunakan teknologi sederhana. Realita inilah yang tidak bisa dipungkiri bahwa kondisi sosial ekonomi para pelaku usaha perikanan dan kelautan Kabupaten Garut umumnya memiliki pendapatan dan kesejahteraan yang masih rendah.

\section{Profil Responden}

Pemilihan responden dilakukan secara acak dari 7 Kecamatan Pantai di Kabupaten Garut yaitu Kecamatan Bungbulang, Caringin, Pakenjeng, Mekarmukti, Cikelet, Cibalong dan Pameungpeuk. Jumlah responden sebanyak 100 Orang dari total 4765 orang nelayan. Berdasarkan hasil penelitian menunjukkan bahwa jenis kelamin responden semuanya adalah pria sejumlah 100 orang (100\%). Hal ini mengimplikasikan bahwa usaha penangkapan ikan didominasi kaum lelaki sementara para wanita nelayan lebih 
berkecimpung di usaha pengolahan hasil ikan ataupun pedagang ikan.

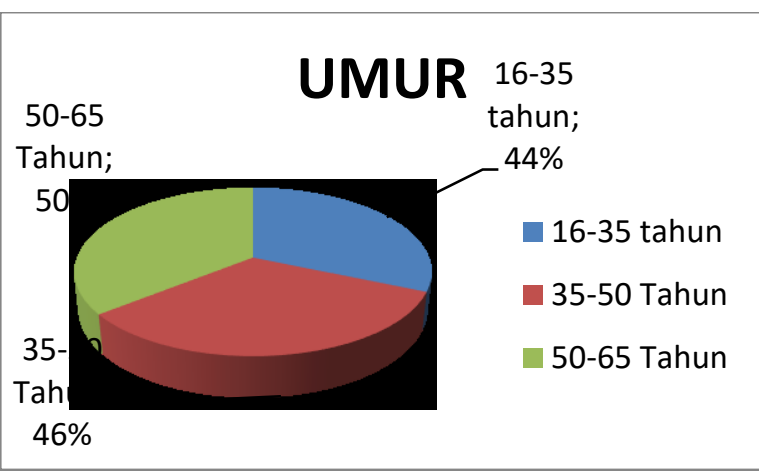

Gambar 1. Usia Responden

Lebih lanjut, usia responden dalam penelitian menunjukkan bahwa usia produktif mendominasi sebagai responden contohnya antara 16-35 tahun dengan besaran $44 \%$ dan sama hal nya juga seperti usia antara 35-50 tahun yaitu $46 \%$. Sebanyak $10 \%$ responden berusia mulai dari 50-65 tahun. Usia produktif antara 39-49 tahun dipercaya oleh responden sebagai usia melaut yang optimal karena pada usia tersebut ketahanan fisik dianggap mampu bertahan dalam alam yang buruk.

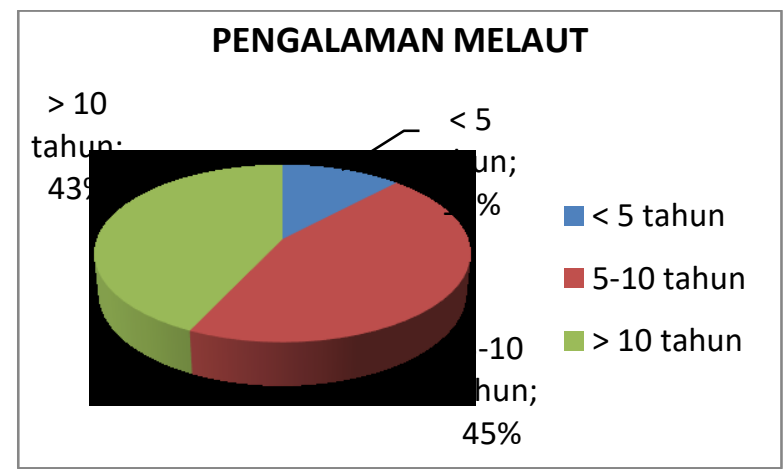

Gambar 2. Pengalaman Responden

Sementara itu, pengalaman melaut responden ternyata 12 Orang melaut kurang dari 5 tahun, 45 Orang diantara 510 tahun dan 43 Orang telah melaut lebih dari 10 tahun.

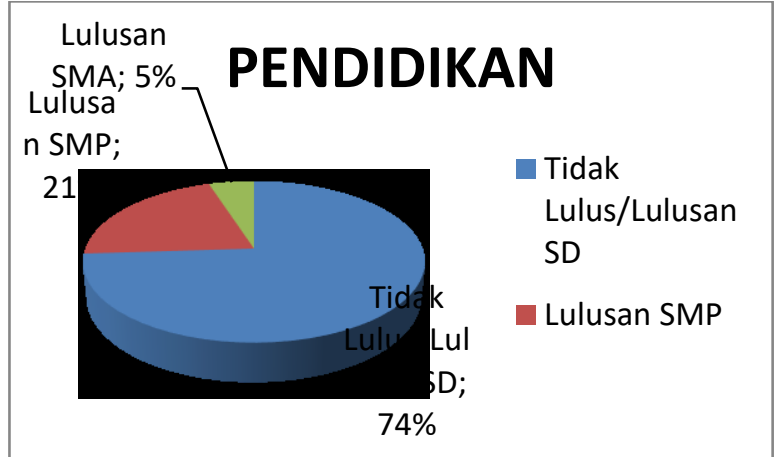

Gambar 3. Pendidikan Responden

Dalam hal pendidikan, $74 \%$ responden merupakan tidak lulus dan lulusan SD, $21 \%$ lulusan SMP, dan $5 \%$ lulusan SMA. Hal ini menjelaskan bahwa tingkat pendidikan para nelayan cukup rendah. Oleh karena itu, diprediksi akan kesulitan dalam menerapkan teknologi terbaru dalam usaha penangkapan ikan dilaut.

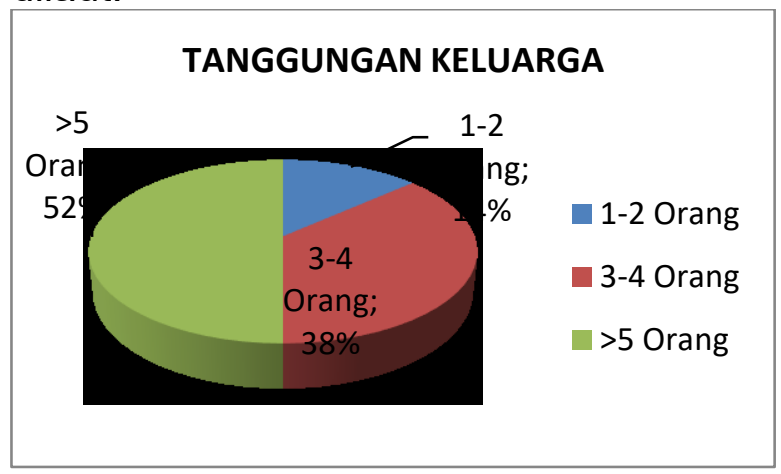

Gambar 4. Tanggungan Responden

$100 \%$ responden menyatakan telah menikah dengan tanggungan keluarga 12 Orang sebanyak 14\%, 3-4 orang tanggungan sebanyak $38 \%$ dan $52 \%$ menyatakan memiliki tanggungan 5 Orang atau lebih. Penemuan ini mengindikasikan bahwa kehidupan para nelayan cukup berat karena memiliki tanggungan hidup yang cukup banyak sehingga mereka harus lebih bekerja keras dalam mencari penghidupan melalui penangkapan ikan di laut. 


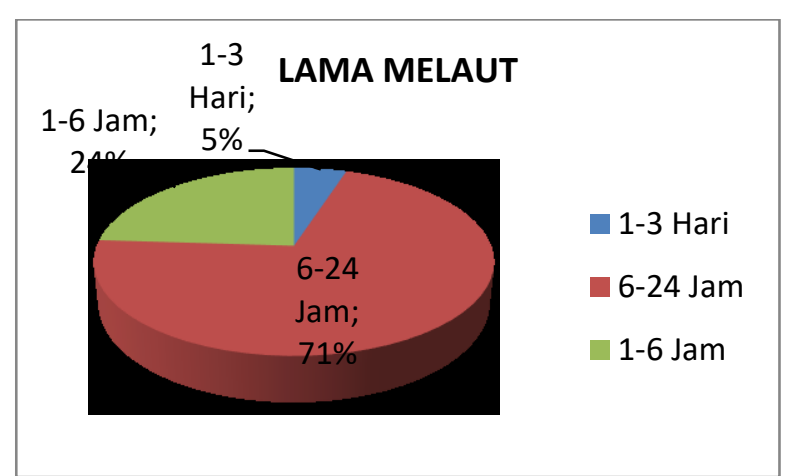

Gambar 5. Lama Melaut Responden

Selanjutnya

responden

menggunakan armada penangkapan yaitu 5 Orang menggunakan Kapal Motor, 71 Orang menggunakan Perahu Motor Tempel; juga 24 Orang menggunakan Perahu tanpa motor. Hal ini berarti nelayan yang menggunakan kapal motor bisa melaut per trip hingga 13 hari atau sekitar 5\% responden, 71\% bisa melaut per trip selama 6-24 Jam dan nelayan andon hanya sanggup melaut per trip sekitar 1-6 jam atau sekitar $24 \%$. Sementara itu alat tangkap yang biasa dipergunakan nelayan melaut yaitu pancing, jaring sirang, jaring insang, serta perangkap. Adapun, hasil tangkapan nelayan merupakan berbagai jenis ikan seperti ikan layur, ikan bawal, ikan kakap, ikan kuwe, ikan tenggiri, ikan tongkol, lobster, cumi dan ikan campur lainnya. Namun tidak semua hasil melaut ini dijual sebagian digunakan untuk keperluan keluarga sehari-hari. Adapun pendapatan nelayan murni setelah dikurangi modal dan pembagian hasil antara ABK menunjukkan bahwa $35 \%$ pendapatan responden Kurang dari Rp. 150.000,- per trip; $63 \%$ berpendapatan diantara Rp 150.000,- hingga Rp 350.000 ,- per trip dan sisanya $2 \%$ berpendapatan lebih dari Rp. 350.000,per trip.

Apabila dibandingkan dengan penggunaan armada diketahui bahwa penghasilan nelayan yang menggunakan Kapal motor memiliki rata-rata penghasilan Rp. 391.200/trip, perahu motor tempel Rp. 275.650/trip dan yang terakhir nelayan andon atau menggunakan perahu tidak bermotor Rp. 115.000/trip. Hal ini menunjukkan semakin sulitnya nelayan mendapat ikan di perairan Kabupaten Garut padahal MSY lestari di kabupaten Garut adalah 10.000 ton/tahun dan hal ini cukup besar untuk para nelayan tang kap dengan hasil yang lebih besar.

\section{Analisis Regresi}

Penelitian menunjukkan bahwa hasil regresi linier dapat digambarkan dengan persamaan sebagaimana dibawah :

$$
\begin{aligned}
\operatorname{Ln} Y=1,485 & +0,787 \operatorname{Ln} X 1 \\
& +0,239 \operatorname{Ln} X 2+0,156 \operatorname{Ln} X 3 \\
& +0,168 \operatorname{Ln} X 4+0,326 \operatorname{Ln} X 5
\end{aligned}
$$

Arti yang dapat diambil dari persamaan adalah :

a. Konstanta $=1,485$

Jika variabel Umur (X1), Pendidikan (X2), Tanggungan Keluarga (X3), Pengalaman (X4), dan Lama Melaut (X5) secara konstan tidak ada peningkatan atau tetap (0), maka pendapatan akan terjadi kenaikan sejumlah 1,485 satuan.

b. Koefisien Umur =0,787

Jika terjadi peningkatan variabel umur sejumlah satu satuan, sementara Pendidikan (X2), Tanggungan Keluarga (X3), Pengalaman (X4), dan Lama Melaut (X5) dianggap tetap akan terjadi kenaikan pendapatan sejumlah 0,787 satuan.

c. Koefisien pendidikan $=0,239$

Jika terjadi peningkatan variabel pendidikan terakhir sejumlah satu satuan, sementara umur (X1), Tanggungan Keluarga (X3), Pengalaman (X4), dan Lama Melaut (X5) dianggap tetap akan terjadi 
kenaikan pendapatan sejumlah 0,239 satuan.

d. Koefisien tanggungan $=0,156$ Jika terjadi peningkatan variabel tanggungan keluarga sejumlah satu satuan, sementara umur (X1), pendidikan (X2), Pengalaman (X4), dan Lama Melaut (X5) dianggap tetap akan terjadi kenaikan pendapatan sejumlah 0,156 satuan.

e. Koefisien Pengalaman $=0,168$ Jika pengalaman mengalami peningkatan sebesar satu satuan, sementara umur (X1), pendidikan (X2), tanggungan keluarga (X3), dan Lama Melaut (X5) dianggap tetap akan terjadi kenaikan pendapatan sejumlah 0,168 satuan.

f. Koefisien lama melaut $=0,326$

Jika terjadi peningkatan variabel lama melaut sejumlah satu satuan, sementara umur (X1), pendidikan (X2), tanggungan keluarga (X3), dan pengalaman (X4) dianggap tetap akan terjadi kenaikan pendapatan sejumlah 0,326 satuan.

\section{Uji Asumsi Klasik}

Selanjutnya, setelah melakukan analisis regresi maka langkah berikutnya adalah melakukan uji asumsi klasik. Adapun, uji asumsi klasik yang dilakukan dalam penelitian adalah sebagai berikut : uji autokorelasi, uji multikolinearitas dan uji heterokedastisitas.

\section{Uji Autokorelasi}

Uji Autokorelasi dilakukan untuk mengetahui adanya hubungan variabel dalam suatu model prediksi dengan suatu perubahan waktu. Sehingga, apabila asumsi autokorelasi terjadi maka nilai disturbance tidak lagi berpasangan secara bebas, melainkan berpasangan secara autokorelasi. Penelitian ini menggunakan kriteria penerimaan sebagai berikut (Gujarati \& Porter, 2009):

- Jika prob.Obs $* R 2<$ alpha $=$ $5 \%$, maka terdapat autokorelasi
- Jika prob.Obs $* R 2>$ alpha $=$ $5 \%$, maka tidak terdapat autokorelasi

Tabel 1. Hasil Uji Breusch-Godfrey Breusch-Godfrey Serial Correlation LM Test:

\begin{tabular}{ll}
\hline F-statistic 1.7654 & Probability 0.29775 \\
Obs*R-squared 4.8393 & Probability 0.2854
\end{tabular}

Sumber : Pengolahan Data (2019)

Berdasarkan uji autokorelasi yang mengaplikasikan metode BreuschGodfrey ditemukan probabilitas Obs * R2 sebesar 0.2854 , dimana nilainya lebih besar dari alpha 5\%. Dan dapat disimpulkan tidak terdapat autokorelasi.

\section{Uji Multikolinearitas}

Uji Multikolinearitas digunakan untuk melihat ada hubungan yang kuat antara dua variabel bebas atau lebih dalam sebuah model regresi berganda. Multikolinearitas dapat juga dilihat melalui nilai Tolerance dan melalui lawannya Variance Inflation Factor (VIF) (Ghozali, 2005). Analisis ini seharunya bisa menjawab tingkat kolinearitas yang masih bisa ditoleransi, Dimana ketika nilai tolerance rendah maka akan sama dengan nilai VIF tinggi (karena VIF = $1 /$ tolerance) dan menunjukkan adanya kolinearitas yang tinggi. Nilai cutoff yang umum dipakai adalah nilai tolerance 0,10 atau sama dengan nilai VIF di atas 10.

Dari hasil penelitian terlihat hasil pengujian multikolinieritas bahwa semua nilai VIF variabel-variabel pada penelitian ini kurang dari 10, dengan kata lain tidak terdapat multikolinieritas. Dimana VIF dalam variabel umur adalah 2,897; pendidikan 1,776; tanggungan keluarga 1,547 ; pengalaman 3,659 ; dan lama melaut 3,785 .

\section{Uji Multiheterokedastisitas}

Uji heterokedastisitas dilakukan dalam rangka mengetahui didalam model regresi apakah terjadi ketidaksamaan 


\section{ANALISIS PENDAPATAN USAHA PERIKANAN TANGKAP : PENGALAMAN DARI NELAYAN KABUPATEN GARUT JAWA BARAT}

variance dari residual satu ke yang lain. Jika variance dari residual satu pengamatan ke pengamatan lain tetap, maka disebut homoskedastisitas dan sebaliknya disebut heterokedastisitas.

Tabel 2. Uji Multikolinearitas

Heteroskedasticity Test: ARCH

F-statistic 0.074175 Prob. F(1,47) 0.7841

Obs*R-squared 0.07650 Prob. Chi-Square(1) 0.7803 Sumber : Pengolahan Data (2019)

Kemudian analisis data menunjukkan nilai Obs R-squared setinggi 0.076503 , dimana nilai tersebut lebih kecil apabila dilihat dari nilai $t$ tabel sebesar 1,678, sehingga dapat disimpulkan tidak terdapat heteroskedatisitas. Selain itu, diketahui pula bahwa Nilai prob Obs $R$ squared sebesar 0.7803 . lebih besar apabila dilihat dari nilai tingkat signifikansi sebesar 0,05 sehingga tidak terdapat heteroskedatisitas.

\section{Uji Hipotesis}

Uji hipotesis yng telah dipergunakan pada penelitian pendapatan nelayan ini yaitu Ordinary Least Square (OLS) atau metode regresi kuadrat terkecil. Uji ini bertujuan untuk menjelaskan suatu fenomena ekonomi secara akurat (Gujarati \& Porter, 2009). Adapun, indikator-indikator yang dipergunakan yaitu koefisien determinasi $\left(R^{2}\right)$, uji-F, dan uji-t.

\section{Koefisien Determinasi $\left(\mathbf{R}^{2}\right)$}

Koefisien Determinasi

berfungsi dalam melihat sejauh mana ketepatan yang terbaik dalam sebuah analisis regresi berganda. Apabila nilai $R^{2}$ mendekati angka 1, maka model ini dapat menjelaskan pengaruh variabel independen kepada variabel dependen dengan kuat. Sedangkan kebalikan dapat terjadi apabila nilai $\mathrm{R}^{2}$ mendekati angka 0 (nol), sehingga variasi variabel independen dalam menjelaskan variabel dependen makin lemah (Ghozali, 2005).

Melalui analisis yang telah dilakukan diketahui nilai $R^{2}=0,837$. Hal ini mengindikasikan Variabel independen seperti variabel umur, tanggungan keluarga , pengalaman, pendidikan dan lama melaut dapat menjelaskan secara signifikan pengaruhnya terhadap 3 Bendapatan sebanyak $83,7 \%$. Adapun sisanya sejumlah $16,3 \%$ diperkirakan dipengaruhi oleh variabel-variabel lain yang berada diluar model.

\section{Uji Hipotesis simultan (Uji -F)}

Untuk menguji hipotesis secara simultan digunakan uji-F dengan tujuan untuk mencari pengaruh secara simultan variabel - variabel bebas yaitu pengalaman, umur, tanggungan keluarga, pendidikan, dan lama melaut secara signifikan kepada variabel terikat yakni pendapatan. Apabila koefisien nilai

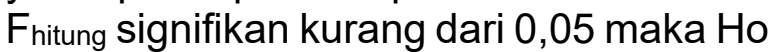
menjadi ditolak dan apabila koefisien nilai Fhitung signifikan lebih besar 0,05 menyebabkan Ho dapat diterima. Selanjutnya, dalam Tingkat signifikan pada $\alpha=5 \%$, diketahui $F_{\text {hitung }}>F_{\text {tabel, }}$ maka $\mathrm{H}_{0}$ ditolak, hal ini mempunyai arti keseluruhan variabel independen secara signifikan berpengaruh terhadap variabel dependen. Sebaliknya, bila $F_{\text {hitung }}<F_{\text {tabel, }}$ sehingga $\mathrm{H}_{0}$ diterima yang berarti semua variabel independen secara bersamasama tidak berpengaruh secara signifikan terhadap variabel dependen.

Dari perhitungan dan analisis pada penelitian ini, diketahui nilai $F_{\text {hitung yang }}$ didapat adalah senilai 75,726 dan nilai signifikansi senilai 0,000 pada signifikansi $(0,05)$ derajat, sementara itu nilai $F_{\text {tabel }}$ adalah, 2,25. Sehingga dapat disimpulkan bahwa $F_{\text {hitung }}<F_{\text {tabel }}$ dan

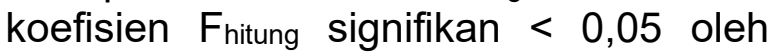
karena itu $\mathrm{Ho}$ ditolak dan disimpulkan variabel independen pendidikan, umur, pengalaman, tanggungan keluarga , dan 
lama melaut secara simultan mempunyai pengaruh secara signifikan kepada variabel pendapatan nelayan.

\section{Uji Parsial (Uji-t)}

Uji $\mathrm{t}$ dilaksanakan dengan tujuan untuk mencari dampak variabel independen baik itu individu maupun terpisah kepada variabel terikat secara signifikan ataupun tidak dengan menganggap faktor lain bersifat tetap. Selanjutnya, apabila nilai koefisien thitung signifikan kurang dari 0,05 menyebabkan Ho tertolak, tetapi apabila nilai koefisien thitung signifikan lebih besar dari 0,05 menyebabkan Ho dapat diterima. Lebih lanjut, apabila nilai thitung lebih besar dari tabel, menyebabkan $\mathrm{H} 0$ ditolak, ini berarti variabel independen ketika parsial signifikan berpengaruh kepada variabel terikat. Tetapi apabila nilai Fhitung kurang dari nilai $F_{\text {tabel, }}$ menyebabkan $\mathrm{HO}$ dapat diterima yang berarti variabel bebas dalam keadaan mandiri tidak berpengaruh secara signifikan kepada variabel terikat.

Menilai uji yang telah dilaksanakan, diketahui hasil regresi ternyata cukup seragam dalam interpretasinya yaitu :

1) nilai thitung variabel umur senilai 5,767 , adapun nilai $\mathrm{t}$ tabel yaitu sebesar 1,847 pada $\alpha=5 \%$ dan diperoleh nilai signifikansinya adalah 0,000 . Sehingga, diketahui bahwa signifikansi $<\alpha(0,05)$ dan thitung $5,767>t_{\text {tabel }} 1,847$ sehingga umur berpengaruh secara positif dan nyata kepada tingkat pendapatan nelayan di Kabupaten Garut.

2) nilai $t$ hitung variabel pendidikan senilai 1,455 , adapun nilai $t$ tabel diketahui senilai 1,847 pada $\alpha=5 \%$ dan diperoleh nilai signifikansinya adalah 0,000 . Sehingga, diketahui bahwa signifikansi $<\alpha(0,05)$ dan thitung $1,455>$ ttabel 1,847 sehingga pendidikan tidak berpengaruh dan nyata kepada pendapatan nelayan Garut.
3) t hitung yang diperoleh dalam variabel tanggungan keluarga adalah senilai 2,378, adapun $\mathrm{t}$ tabel yang diperoleh senilai 1,847 pada $\alpha=5 \%$ dan diperoleh nilai signifikansinya adalah 0,002 . Sehingga, diketahui bahwa signifikansi $00,002<\alpha(0,05)$ kemudian thitung 2,378> tabel 1,847 sehingga tanggungan keluarga mempunyai pengaruh positif dan nyata kepada tingkat pendapatan

4) $t$ hitung yang diperoleh dalam variabel pengalaman senilai 4,332 , adapun $\mathrm{t}$ tabel yang diperoleh senilai 1,847 pada $\alpha=5 \%$ dan diperoleh nilai signifikansinya adalah 0,002 . Sehingga, diketahui bahwa signifikansi $0,002<\alpha$ $(0,05)$ kemudian thitung 4,332 > tabel 1,847 sehingga pengalaman berpengaruh nyata dan positif kepada tingkat pendapatan

5) t hitung yang diperoleh dalam variabel lama melaut senilai 6,327 , adapun $\mathrm{t}$ tabel yang diperoleh senilai 1,847 pada $\alpha=5 \%$ dan diperoleh nilai signifikansinya adalah 0,000 . Sehingga, diketahui bahwa signifikansi $<\alpha(0,05)$ kemudian thitung 6,327> tabel 1,847 sehingga lama melaut mempunyai pengaruh secara nyata dan positif terhadap tingkat pendapatan

\section{Pembahasan}

Berdasarkan hasil analisis juga menggambarkan bahwa umur nelayan mempunyai pengaruh kepada pendapatan nelayan. Penjelasannya diperkirakan karena usia produktif dapat bekerja dengan lebih kerja dan memiliki tenaga yang lebih besar daripada usia non-produktif. Hal ini dikarenakan dalam penelitian ini usia responden yang periode masa periode masa produktif hampir mendominasi dengan persentase sekitar 90\%. Oleh karena itu umur nelayan di Kabupaten Garut dapat mempengaruhi pendapatan para nelayan. Usia dapat dikatakan menjadi 
salah satu variabel yang mempunyai pengaruh kepada pendapatan (Cahyono, 1998). Kekuatan fisik ketika beraktivitas sangat erat kaitannya dengan umur. Dimana apabila usia masa produktif terus berkurang akan berpengaruh terhadap penurunan kekuatan fisik akibatnya produktivitas kerja menjadi lebih turun sehingga pendapatan pun ikut menjadi turun (Putri \& Setiawina, 2013).

Selanjutnya, Pendidikan diakui merupakan cara yang penting dalam kehidupan bermasyarakat untuk meningkatkan kualitas dan kesejahteraan hidup. Akan tetapi, hasil analisa menggambarkan bahwa pendidikan tidak mempunyai pengaruh dan tidak signifikan secara parsial kepada pendapatan nelayan di Kabupaten Garut. Hasil survei menunjukkan Tingkat pendidikan akhir para responden ternyata beragam, tetapi bila diperbandingkan dengan pendapatan ternyata sama saja. Sebagai contoh diketahui bahwa sebagian besar nelayan yang tamatan SD mempunyai pendapatan yang nyaris sama dengan mereka yang lulusan SMP maupun SMA. Hal ini menunjukkan bahwa ada faktor lain yang mempengaruhi pendapatan tetapi bukan pendidikan. Hal ini dikarenakan usaha penangkapan ikan secara tradisional yang terjadi di Kabupaten Garut merupakan sektor informal, tidak memerlukan ijazah tetapi lebih kepada soft skill, pengalaman dan tenaga.

Ditemukan pula bahwa tanggungan nelayan berpengaruh terhadap pendapatan nelayan. Lebih banyaknya jumlah yang menjadi tanggungan keluarga menyebabkan semakin besar ongkos kehidupan yang harus dipenuhi kepala keluarga. Hal ini menjadi pemicu semakin giatnya para nelayan untuk mencukupi kebutuhan hidup keluarganya. Kondisi ini dinyatakan ketika terjadi peningkatan dalam jumlah tanggungan rumah tangga maka terjadi pula penambahan pendapatan para nelayan di Kabupaten Garut.

Selain itu, analisis menggambarkan ketika pengalaman nelayan mempunyai pengaruh kepada pendapatan nelayan. Kondisi ini diperkirakan karena banyaknya pengalaman seorang nelayan dalam mencari ikan maka dia dapat lebih mengenai kondisi lautan dengan menggunakan instingnya dan mengetahui perawatan armada dan alat tangkapnya. Dalam Peningkatan pendapatan dari sisi kuantitas dan kualitas membutuhkan pengalaman tenaga pekerja. Hal ini karena pengalaman merupakan satu langkah dalam pembangunan modal manusia. Dimana modal ini akan membantu modal fisik yang secara produktif dalam aktivitas nya dimana apabila tidak digunakan dapat mengakibatkan mesin dapat lebih cepat rusak dan menjadi tidak digunakan, bahan baku dan unsur menjadi terbuang serta kualitas dan kuantitas hasil rendah (Jhingan, 2012). Hal inilah ditemukan di nelayan Kabupaten Garut dimana ratarata nelayan dengan pengalaman 10 tahun ke atas memiliki pendapatan yang lebih besar daripada nelayan dengan pengalaman kurang dari 5 tahun. Modal sumber daya manusia yang didapat melalui pembentukan pengalaman kerja dapat memastikan banyaknya produksi barang dan jasa. Semakin lama pengalaman kerja semakin tinggi hasil yang didapatkan, demikian pula ketika semakin sedikit pengalaman seseorang semakin sedikit pula hasil yang didapatkannya (Mankiw, 2011).

Dan terakhir, lama melaut memiliki pengaruh yang signifikan kepada pendapatan para nelayan kabupaten Garut. Kondisi ini dikarenakan adanya kompetisi antar nelayan di daerah pinggir laut dimana nelayan andon, nelayan PMT berlomba mencari ikan disana. Di Kabupaten Garut ditemukan fakta bahwa nelayan dengan PMT memiliki 
pendapatan yang lebih banyak apabila dibandingkan nelayan pinggiran yang berusaha di sekitar pantai.

Oleh karena itu, nelayan yang mencari ikan lebih jauh ke lepas pantai memiliki kesempatan yang lebih besar dalam menghasilkan jumlah tangkapan ikan yang besar meskipun dalam pelaksanaannya membutuhkan lebih banyak waktu dan jarak yang lebih jauh. Tetapi kemungkinan jumlah pendapatan menjadi lebih besar dibandingkan nelayan pantai yang berusaha hanya di dekat pantai (Masyhuri, 1999).

Angka indikator analisis usaha perikanan di Kabupaten Garut sebagaimana yang telah dikemukakan terdahulu, diharapkan mampu menjawab kekurangan dalam input pengambilan keputusan dan salah satu landasan untuk Pemerintah Kabupaten Garut dalam mengambil Kebijakan untuk meningkatkan kesejahteraan nelayan. Pendapatan usaha nelayan tangkap di Kabupaten Garut menunjukkan bahwa teknologi perikanan melalui armada tangkap ternyata berpengaruh terhadap pendapatan nelayan. Seperti halnya di Kabupaten Jeneponto, Barru, dan Sinjai Sulawesi Selatan diperkirakan rata-rata pendapatan nelayan perahu motor memiliki pendapatan usaha tangkap lebih besar daripada nelayan perahu tanpa motor (Rahim, 2010).

\section{PENUTUP}

Menindaklanjuti penelitian dapat ditarik sebuah kesimpulan yaitu apabila secara bersama variabel umur, pengalaman , pendidikan, tanggungan keluarga, dan lama melaut berpengaruh secara signifikan terhadap pendapatan usaha nelayan. Sementara itu, apabila secara tersendiri hanya 4 variabel yang berpengaruh secara positif kepada pendapatan nelayan tangkap yaitu lama melaut, umur nelayan, tanggungan keluarga dan pengalaman. Sedangkan pendidikan terakhir formal tidak berpengaruh secara nyata kepada pendapatan para nelayan tangkap.

Selanjutnya, rekomendasi aplikatif yang dapat diusulkan adalah kepada Pemerintah Kabupaten Garut dalam upaya untuk meningkatkan kesejahteraan nelayan yang dilihat dari pendapatannya diharapkan melakukan sosialisasi kepada nelayan agar segera membentuk kelompok nelayan koperasi dengan komposisi anggota yang bervariasi dalam hal umur, pengalaman dan tanggungan keluarga sehingga terjadi keseimbangan antar awak nelayan dalam usaha penangkapan ikan. Selanjutnya, mulai menghimbau para nelayan untuk meninggalkan profesi nelayan andon untuk beralih menjadi nelayan dengan PMT sehingga dapat menjangkau kawasan laut yang lebih jauh. Lebih jauh, dengan adanya kelembagaan nelayan dapat lebih memudah Pemerintah daerah dalam memberikan bantuan sarana dan prasarana penangkapan dan akses ke permodalan melalui rekomendasi ke bank. Pemerintah Daerah pun harus terus melakukan penyuluhan dan pembinaan dalam bentuk bimbingan teknis ataupun diklat-diklat kepada nelayan guna peningkatan wawasan ilmu pengetahuan nelayan tentang ilmu dan teknologi penangkapan ikan serta terus melakukan sosialisasi pentingnya pendidikan. Dimana dengan pendidikan akan menghasilkan kualitas dan peningkatan skill terhadap anak, serta dapat meningkatkan pendapatan nelayan.

Adapun, rekomendasi secara akademik yaitu supaya dilakukan penelitian lanjutan dengan mempertimbangkan variabel ekstrinsik seperti permodalan, jenis pekerjaan nelayan, jenis armada, dan musim. Hal ini dikarenakan diperkirakan dalam 
melakukan analisis pendapatan tidak bisa dilihat hanya dari segi faktor intrinsik nelayan tetapi juga dari faktor luar tadi sehingga penelitian bisa lebih komprehensif.

\section{DAFTAR PUSTAKA}

Ali, K., Dharmawan, A., Saharuddin, Alfiasari, Sukandar, D., \& Syarief, H. (2015). Indikator Kemiskinan dan Misklasifikasi Orang Miskin. Jakarta: Yayasan Pustaka Obor Indonesia \&Fakultas Ekologi Manusia IPB.

Béné, C., \& Friend, R. (2011). Poverty in small-scale fisheries. Progress in Development Studies, 11(2), 119144. doi:10.1177/146499341001100203.

Cahyono, S. (1998). Karakteristik Sosial Ekonomi yang Mempengaruhi Pendapatan Rumah Tangga Penyadap Getah Pinus di Desa Somagede, Kebumen, Jawa Tengah. Jurnal UGM.

Everett, A., \& Ebert, R. (1992). Production and operations management : concepts, models, and behavior 5 th $\mathrm{Ed}$. Englewood Cliffs, NJ: Prentice Hall.

Ghozali, I. (2005). Aplikasi analisis multivaria dengan program SPSS. Semarang: Badan Penerbit Universitas Diponegoro.

Gujarati, D. N., \& Porter, D. C. (2009). Basic Econometrics, 5th Edition, International Edition. Singapore: McGraw Hill Ltd.

Halim, D., \& Susilo, Y. (2013). Faktor Faktor Yang Mempengaruhi Pendapatan Masyarakat Nelayan
Pantai Di Kabupaten Bantul Tahun 2012. MODUS Vol. 25 (2), 171-187.

Indarti , I., \& Kuntari, Y. (2015). Model Pemberdayaan Sumber Daya Masyarakat Pesisir Melalui ReEngineering Ekonomi Berbasis Koperasi Berkelanjutan . PROSIDING SEMINAR NASIONAL MULTI DISIPLIN ILMU E CALL FOR PAPERS UNISBANK (SENDI_U) Kajian Multi Disiplin Ilmu untuk Mewujudkan Poros Maritim dalam Pembangunan Ekonomi Berbasis Kesejahteraan Rakyat. Semarang.

Ismail, Z. (2004). Pengembangan potensi sosial ekonomi masyarakat wilayah pesisir yang berkelanjutan. Jakarta: Pusat Penelitian dan Pengembangan Ekonomi dan Pembangunan (PEP-LIPI).

Jhingan, M. L. (2012). Ekonomi Pembangunan dan Perencanaan. Jakarta: Rajagrafindo Persada.

Kusnadi. (2009). Keberdayaan Nelayan dan Dinamika Ekonomi Pesisir. Jogjakarta: Ar-Ruzz Media.

Mankiw, G. (2011). Principles of Economics, 5 th edition. South-Western Cengage Learning.

Masyhuri. (1999). Usaha Penangkapan Ikan di Jawa dan Madura: Produktivitas dan Pendapatan Buruh Nelayan. Masyarakat Indonesia, XXIV, No. 1.

Monintja, D., \& Yusfiandani, R. (2011). Pemanfaatan Sumberdaya Pesisir Dalam Bidang Perikanan Tangkap. Prosiding Pelatihan 
Pengelolaan Wilayah Pesisir Terpadu. Bogor: Institut Pertanian Bogor.

Puluhulawa, J. N., Rauf, A., \& Halid, A. (2016). Analisis Faktor-Faktor Yang Mempengaruhi Hasil Tangkapan Nelayan Di Kecamatan Bilato Kabupaten Gorontalo. AGRINESIA : Jurnal Ilmiah Agribisnis Vol. I No. 1 November 2016, 43-50.

Putri, A., \& Setiawina, N. (2013). Pengaruh Umur, Pendidikan, Pekerjaan Terhadap Pendapatan Rumaha Tangga Miskin di Desa Bebendam. EJURNAL EKONOMI PEMBANGUNAN UNIVERSITAS UDAYANA Vol. 2, No. 4, April 2013, 173-180.

Rahim, A. (2012). Komparatif Pendapatan Per Trip Musim Penangkapan Nelayan Tangkap Tradisional Perahu Motor Tempel dan Perahu tanpa Motor. Jurnal Ekonomi Pembangunan dan Pertanian Volume 2 Nomor 1 November 2012.

Rahim, A., \& Hastusti, D. (2005). Sistem Manajemen Agribisnis. Makassar: State University of Makassar Press.

Salagrama, V. (2006). Trends in poverty and livelihoods in coastal fishing communities of Orissa state, India. Rome, FAO. 2006. 111p. ISBN 92-5105566-1: FAO Fisheries Technical Paper No. 490.

Samuelson, P., \& Nordhaus, W. (2010). Macroenomics 19th ed. McGrawHill. .

Soekartawi. (2002). Analisis Usaha Tani. Jakarta: UI-Press.
Sudarman, A. (2011). Teori Ekonomi Mikro. In: Pengertian Dasar Fungsi Pasar dan Harga. Jakarta: Universitas Terbuka, pp. 1-29. ISBN 9796895811.

Sugiarto, Herlambang, T., Kelana, S., Brastoro, \& Sudjana, R. (2007). Ekonomi Mikro: sebuah kajian komprehensif. PT Gramedia Pustaka Utama.

Sugiyono. (2013). Metodologi Penelitian Bisnis. Jakarta: Alfabeta.

Wahyono, A., Antariksa, I., Imron, M., \& Indrawasih, R. (2001). Pemberdayaan Masyarakat Nelayan. Jakarta: Media Pressindo. 